\title{
Financial Resources and Product Market Development: Strategic Choice and Institutional Processes During China's Transition
}

\author{
Lisa A. Keister ${ }^{1,2}$ and Jin $\mathbf{L u}^{1}$
}

During an economic transition from socialism, market exchange replaces redistribution. We study firm decisions to enter product markets to understand the factors that influence this process. Managers in Chinese State Owned Enterprises operated within institutional constraints to make strategic decisions, and state intervention shaped which factors were salient. Firms financed through central government and bond issues relied less on markets. Firms funded through local government moved into markets faster; firms funded by banks were initially faster to markets but slower to markets after bank reform shifted lending policies. Thus, the accessibility, flexibility, and stability of financing shaped decisions about market entrance.

KEY WORDS: Chinese transition; organizational theory; market development; economic sociology.

A central component of economic transition from state socialism is the replacement of centrally controlled redistribution by market coordination of economic exchange. Accordingly, the development of markets for producer goods has been a dominant feature of China's transformation. Market exchange of producer goods occurred prior to reform, but it usually involved only small, rural firms and affected a small fraction of total producer good purchases (Wong, 1986). Economic reform allowed firms to begin to engage in market exchange of producer goods for the first time (Naughton, 1995:113). During the 1980s, the state continued to control a large portion

\footnotetext{
${ }^{1}$ Department of Sociology, Ohio State University, 300 Bricker Hall, 190 North Oval Mall, Columbus, Ohio 43210.

${ }^{2}$ To whom correspondence should be addressed; e-mail: Keister.7@osu.edu.
} 
of industrial output, but authorities increasingly allowed firms to buy inputs and sell output with contacts identified by the firm on terms negotiated by the partners to the exchange. Because enterprises were able to retain profits from direct sales, market exchange increased revenues, promoted firm growth, and contributed to aggregate economic expansion (Wu and Zhao, 1987). The linkages firms developed early in reform also reduced interdependence between the state and enterprises, and provided managers with sources of inputs and sales that allowed them to adjust as reform reduced central planning. As a result, these markets facilitated early reform and contributed to the development of a network of interfirm exchange relations necessary for long-term growth.

While the effect of product market expansion on firm performance and productivity has been documented (Walder, 1995), the process by which firms made the transition to markets has received little attention. Even among large, state-owned enterprises, there was considerable variation in the paths firms took during transition. Firms that made the transition varied in the degree to which they committed to using markets. The way in which firms changed affected the rate of market development within and across regions and industrial sectors, and it also shaped the degree to which relations developed among suppliers and customers. The decisions managers made early in the reform about entering markets are thus likely to affect firm growth as transition progresses and to shape the nature of China's economy long after transition is complete.

Organizational response to market development during China's transition also provides a unique opportunity to explore the relative role of organizational and environmental influences in firm behavior, a tension that pervades organization theory. Research on Western firms suggests that either internal incentives and preferences (Dess and Beard, 1984; Keats and Hitt, 1988; Pfeffer and Salancik, 1978) or external pressures (Buchko, 1994; DiMaggio and Powell, 1983; Meyer and Rowan, 1977) determine innovative organizational response. In reality, both internal and external processes are important, but the relative weight of these influences is unclear. One factor that is overlooked in Western studies is the role of the state. We argue that the state's intervention shapes the degree to which internal and external influences are salient. The strong state combined with extreme external pressures and emerging organizational preferences that are common during transition make this an ideal context within which the processes that shape organizational behavior can be understood more clearly.

In this study, we integrate ideas from strategic choice and institutional theory to propose that managers behave within important external constraints to develop a coherent strategy for the firm. In particular, we focus on the role that firm finance plays in shaping adaptation and how state 
behavior mediates this relationship. While decisions about the acquisition of producer goods appear to be among the most purely financial decisions that a firm makes, a variety of factors, only some of which are strictly economic, contribute to this process. First, we argue that access to nonstate funds in a financial market signals an opportunity to reduce dependence on the state and encourages firm expansion to product markets (Byrd, 1989; Keister, 2000:57; Naughton, 1995:106, 113). Second, we argue that not all funding sources have the same effect on firm behavior, and the different effects reflect joint strategic choice and responses to institutional pressures. Receiving central government funding, for example, should reduce expansion to product markets because firms receiving central state support were typically high state priorities and were either not permitted or did not need to experiment with product markets. In contrast, firms receiving local government funds were more flexible because local governments depended more on industry for revenues and thus would have been more likely to encourage experimentation (Walder, 1995).

We use 1980-1989 longitudinal data on 769 Chinese firms to examine the process by which firms began to use product markets in the first decade of reform. We study how firms obtained productive inputs (i.e., raw materials, subsidiary materials, fuel, and purchased power) and how they sold output. ${ }^{3}$ High-dimensional, multivariate probit analyses, logistic, and generalized least-squares analyses of market use and levels of commitment to using markets provide strong support for our arguments that financial market development, bank loans early in reform, and local government funding increased use of markets. The results also reveal that central government funding, bank loans later in reform, and bond issues decreased use of markets.

\section{REFORM AND THE EMERGENCE OF PRODUCER MARKETS}

Prior to economic and industrial reform, local governments in China controlled a large proportion of standardized producer goods, such as coal, cement, and iron. Government agencies engaged in market-like sales and barter of goods across regions. Since firms were required to use government sponsors to operate outside their regions, such transactions were largely limited to local exchange. Small-scale and rural firms were often able to operate independently on the market because competent government sponsors were rare and administrative control was relatively relaxed. As a result, these firms dominated early market transactions for producer goods. In provinces such

\footnotetext{
${ }^{3}$ Purchased power refers to electricity, steam, and other forms of power that firms purchased
} from external sources. These inputs are typically included as production costs in accounting. 
as Jiangsu, where a significant number of rural industries existed, marketlike transactions already accounted for about $25 \%$ of the supply of key raw materials in 1978 (Naughton, 1995:113).

However, for the majority of China's medium- and large-scale, stateowned enterprises, the state regulated exchange and prevented reliance on markets for buying inputs or selling output. State ownership of firms created conflicting incentives for state administrators and firm managers, softened budget constraints, and lead to interdependence between the state and firms (Wong, 1986). As owners of the enterprises, governments had objectives other than efficiency or profitability. They relied on firms to provide scarce inputs to other firms, maintain full employment, fund employee pension plans, and provide medical care, housing, and various other social welfare services (Kornai, 1992; Walder, 1992, 1995). These nonfinancial preferences ultimately outweighed state interest in the financial performance of the firms. Loss-making firms were able to survive as the government constantly reallocated funds obtained from profitable firms to less efficient enterprises. As neither firm survival nor growth was constrained by firms' budgets or financial performance, managers responded by hoarding resources and continuously bargaining with state officials for favorable treatment in much the same way that Eastern European firms responded (Kornai, 1979, 1986). The state was hesitant to discipline public enterprises because it relied on them for revenues and the provision of social welfare.

Prior to reform, there was also no financial market, although banks did exist as state agencies responsible for enacting and enforcing government monetary policy (Lardy, 1998). State-owned enterprises and banks operated on a transfer system of credit controlled by government bureaus. Households and other enterprises used a currency system that had little connection with the credit system of the state-owned enterprises. The funds transferred among banks and state-owned enterprises were not convertible to cash, but the credit and currency systems did influence each other. Yet there was no central bank, and banks were not required to maintain reserves (Holz, 1992). Moreover, while the state began to experiment with monetary policy prior to reform, these policies were subordinate to the procedures that guided the determination and enforcement of output targets (Xu, 1998; Yi, 1994).

Starting in 1978, the Chinese state began to implement widespread industrial reform. Previous research and policy prescriptions assumed that only by replacing state ownership completely could bargaining be eliminated and firms become viable economic entities (Kornai, 1992). However, instead of shifting the state ownership of enterprises to private hands immediately, China's reformers first focused on improving firm autonomy and developing incentive mechanisms for managers and workers in state enterprises. Firms gained the right to retain profits and obtained unprecedented 
control over output beyond mandatory plan targets (Jefferson and Rawski, 1994). Market transactions, previously only tolerated, were now encouraged to promote efficiency, independence, and ultimately financial performance. Firms, particularly those in the coastal areas, had increasing contact with foreign firms and products as international trade and investment expanded.

In 1984, the state introduced a dual pricing system that shaped firms' adoption of market exchange practices in important ways. The purpose of this reform was to differentiate supplies of industrial goods into plan and market components. Under this system, firms were able to exchange marginal quantities of industrial inputs and outputs in markets where supply and demand determined prices. Reformers first implemented the dual pricing system in a limited number of regions and allowed only certain firms to participate, but before long, most firms in nearly all regions were able to participate. Because the same good could now be sold at very different prices depending on the allocation mechanism that regulated its sale, shortages developed, and significant disparities between prices in markets and within the plan emerged during the early stages of this reform. Of course, this increased the incentives firms faced to move to markets, particularly given that state administrators had begun applauding market-oriented behavior.

Simultaneously, banking reform changed the way managers financed firms. In 1983, direct grants to State Owned Enterprises (SOEs) were replaced by interest-bearing loans in order to harden budget constraints. The People's Bank of China (PBOC) was separated from the Ministry of Finance and became the central bank in 1984. The PBOC gradually assumed control of the money supply and began to set monetary policy, regulate exchange rates, and oversee the financial system. Under the central bank, four specialized banks emerged as financial intermediaries. The Industrial and Commercial Bank, the Agricultural Bank, the People's Bank, and the Construction Bank remained government agencies, but they gradually began to accept deposits and to lend capital without government intervention. Although their names identified the specialized banks with particular segments of the economy, the banks were free to lend to firms in all industries. Firms applied for funds, and their requests were increasingly evaluated on the merit of the particular firm and the application, with decreasing regard for government policy. Yet these banks remained government agencies, and their lending at times reflected state policy more than the financial objectives of the bank (Goldie-Scott, 1995; Yi, 1994).

As a result of these changes, a growing number of firms started to actively seek access to markets for both productive inputs and industrial output (Wong, 1986). The first decade of China's economic reform witnessed a visible shift from planning to the market for most state enterprises and rapid industry growth led by the state sectors. China's real output increased almost 
fivefold from 1980 to 1992 , with the majority contributed by state-sector enterprises (Jefferson and Rawski, 1994). Many state enterprises adapted quickly to markets and simultaneously began improving their financial performance. However, not all firms made this transition quickly, if at all. Why did some managers adopt market practices while others lagged behind? How did this process unfold in China in the first decade of reform, and what were the firm and institutional conditions that influenced this process? More generally, how do strategic and institutional processes affect organizational decision makers as they develop strategic response to external shocks?

\section{FIRM FINANCE AND ADAPTATION TO MARKETS}

In strategy research in developed market economies, strategic choice ideas and institutional theory dominate studies of innovative behavior. Strategic choice approaches, such as resource dependence theory, emphasize factors internal to the firm. Penrose (1959), Nelson and Winter (1982), Barney (1986,1991), and a host of others (Barnett, 1993; Dutton and Duncan, 1987; Ginsberg, 1988; Tichy, 1983) argue that internal firm traits determine the nature and timing of innovation. Managerial knowledge, organizational expertise and related capabilities, and a preference for autonomy from outside organizations shape firm decisions. From this perspective, firms' unique knowledge and capabilities allow managers to undertake new activities that, under the right set of internal and external conditions, may improve performance and long-term competitive position (Ginsberg, 1988). Innovation occurs when the firm has the necessary internal resources and capabilities to change, and the change appears to be in its interest, given available information (Kelly and Amburgey, 1991).

In other research, external environmental factors have been shown to create incentives for altering organizational structures and strategic orientations. Research from an institutional perspective emphasizes that external organizations and pressures shape firm behavior (Buchko, 1994; DiMaggio and Powell, 1983; Meyer and Rowan, 1977). Institutional ideas are more commonly used to study similarities among organizations than as a lens for understanding structural change in organizations (Buchko, 1994; DiMaggio and Powell, 1983; Meyer and Rowan, 1977). In some of the works that identify the basic ideas underlying the approach, however, institutionalization is conceived of as both a process and a property that is usefully extended to discuss change (DiMaggio and Powell, 1983; Zucker, 1977). In these works, institutional theory distinguishes radical from incremental change (Dougherty, 1994; Greenwood and Hinings, 1996), identifies the contextual conditions under which change occurs (Leblebici et al., 1991; Oliver, 1991), 
and identifies the conditions under which ideas are diffused among organizations (Haunschild and Miner, 1997; Strang and Meyer, 1993; Tolbert and Zucker, 1983). Managerial innovation most commonly results from pressure from external organizations, external normative pressure, or a need for legitimacy.

Although research from these two perspectives often attempts to explain similar behaviors, the theories are seldom used together. Previous literature suggests that either strategic choice factors or institutional factors dominate firm behavior. In reality, both strategic choice and institutional factors are likely to shape firm behavior in all contexts. The importance of both strategic and institutional influences is likely to be particularly evident when firms are adapting to radical change because stagnant managerial decision making is impossible. Indeed, drawing on ideas from both perspectives may provide a deeper understanding of organization actions. Moreover, the strong role that China's state took in reform provides a unique opportunity to explore which portions of each perspective are relevant in which situations. That is, the state's intervention likely shaped the degree to which internal and external influences were salient.

\section{FINANCIAL MARKET DEVELOPMENT AND USE OF PRODUCT MARKETS}

A firm's capacity to transit to markets depends both on a firm's internal incentives to alter its behavior and on external opportunities to change the way business is done. During economic transition in China, fiscal constraints influenced much of organizational decision making because they affected both willingness and opportunities (Guthrie, 1997:143-145; Keister, 2000:7577). The degree to which financial markets were developed, in particular, affected both manager preferences and the availability of opportunities to engage in market exchange. When managers encounter uncertainty, they nearly universally seek ways to reduce risk (DiMaggio and Powell, 1983; O'Neill et al., 1998). In transition economies where uncertainty associated with poorly developed markets is particularly salient, managers are especially attuned to the need to protect their interests (Guthrie, 1997:98-100; Keister, 2001; Peng, 2000). In China, in areas where financial markets were more developed, financing was relatively easy to obtain. As a result, managers were more certain that they would have funds to continue operating in the future, they were more certain that their potential trade partners would have funds to pay for goods, and they were more confident that markets would be stable enough to sustain repeated exchange.

Consistent with strategic-choice arguments, managers experimented because they perceived that they had the capability to change. They were 
likely to be able to withstand the additional risk that would accompany experimentation with a new form of exchange. Consistent with institutional arguments, firms likely perceived lower risk associated with market experimentation in areas with developed markets. Specifically, where financial markets were relatively well-developed, managers likely experienced an environment in which confidence in finance was high, regardless of the type of funding the firm itself received. Moreover, in areas with relatively welldeveloped financial markets, normative pressure to use markets began to expand and further compelled managers to experiment with product markets. As a result, firms located in areas with relatively well-developed financial markets were more likely to experiment with product markets, regardless of the type of funding they received, than their counterparts located in areas with less-developed financial markets. In particular, firms located in areas with more-developed financial markets were more likely to use markets for obtaining and selling products. These firms were also likely to be more committed to using markets and, therefore, to use product markets for a larger portion of their total transactions.

\section{FUNDING SOURCES AND USE OF PRODUCT MARKETS}

While the market context was clearly important, the strong state in China continued to shape a great deal of economic behavior during transition. Indeed, many of China's state-owned enterprises continued to receive large amounts of funding from the central government. These firms were usually high priorities for the state because they were dominant firms in vital industries (e.g., defense, telecommunications), provided essential jobs, contributed important resources to the state, or were otherwise deemed critical. Firms that were high priorities did not face the same uncertainties that other firms faced and were either not permitted or did not need to experiment with product markets. For these firms, both internal incentives and external institutional pressures advocated avoiding markets. This does not suggest that managers were not behaving strategically nor that they were not affected by institutional pressure. Rather, the strong relationship these firms continued to have with the state meant that a particular type of institutional pressure-market uncertainty—was largely irrelevant. Strategic decision making dictated not experimenting with markets but rather continuing to foster a relationship with the strongest institutional force in the economy: the state. For this reason, it is likely that firms receiving central government funds were less likely to use markets for obtaining and selling products. It is also likely that these firms used product markets for a smaller portion of their total transactions. 
An important way in which states affect the constraints and incentives that firms face is through legislative action. An example from China's transition of how state legislation can affect firm behavior is the grants-for-loans legislation enacted in 1983. The central government passed this legislation at the same time that it was reducing its overall patronage of firms. As the state reduced its financial support of firms in the early 1980s, nonstate funds became more appealing. In many cases, nonstate funds were more certain, involved less political maneuvering and bargaining to maintain, and had the potential to eliminate problems related to supply shortages. In addition, nonstate capital allowed managers to reduce their dependence on the state, which reduced uncertainties about levels of state funding and decreased the risk of having profits redirected to loss-making firms (Keister, 2001). As a result, many enterprises started to actively seek external funding, including bank loans, loans from other companies, investment from other companies, and equity and bond issues to raise capital.

Despite the increasing number of options, bank loans were the most common form of external finance in the early 1980s for at least two reasons. First, bank loans were relatively easy to obtain; second, these loans were fairly low risk because they were backed by the state. Because receiving bank loans was an important indicator of firm position in the state hierarchy and because loans indicated elements of firm strategy, receiving loans affected a firm's willingness to experiment with product markets. In particular, in the first few years of reform, firms that received bank loans were more likely to experiment with markets because these firms were relatively low state priorities. Firms seeking external funds in the early stages of reform may have been released from government control early and thus faced external pressure to find new ways to replace other functions that the state used to fill, including obtaining productive inputs and marketing output. Firms that received bank loans, as opposed to those who had not been able to secure loans, however, also likely felt a degree of security. Because bank loans often involved relatively little risk, they could be regarded as an intermediate form of finance for managers who were reluctant to assume the risk of borrowing from wholly nonstate sources (Goldie-Scott, 1995). The amount of bank loans a firm was able to obtain directly affected its ability to conceive of or implement strategies that were instrumental to improving efficiency and effectiveness during the reform.

Following the financial reforms of 1983, however, the meaning of bank loans changed. Recall that in 1983, the state replaced direct grants to SOEs with interest-bearing loans. At that point, bank loans became higher risk because they had interest associated with them. Enterprises that were still receiving bank loans after 1984 may not have had other alternatives because they were not adapting to financial markets yet. Similarly, after 1983, there 
was normative pressure to begin using forms of finance that were entirely nonstate. Thus it is likely that state action in 1983 changed the meaning of both internal strengths and external pressures, and firms that were still receiving bank loans after 1984 were less likely than their counterparts to adapt to developing product markets. More specifically, prior to 1984, firms that received bank loans were more likely to use markets for obtaining and selling products than firms that did not. Firms with bank loans were also more likely to use product markets for a larger portion of their total transactions before 1984. However, after 1984, firms with bank loans were less likely to use markets for obtaining and selling products than their counterparts that did not receive loans and likely used product markets for a smaller portion of their total transactions.

Yet another way that China's central state affected firms was by increasingly transferring control of firms to lower levels of government. China's economy was characterized by significant regional differences even in the pre-reform era. Prior to reform, planning was done not only at the central government level, but also at various local levels, including province, city, county, and even townships (Wong, 1986). Local governments controlled most physical and financial resources and played an important role in shaping the institutional environment in which firms were embedded. Although development of product markets following reform allowed firms to be less dependent on administrative allocations, local governments remained important primarily because of their control of financial resources (Wong, 1986). In the early stages of reform, local governments received funds from firm profits and taxes as a result of fiscal decentralization. They also influenced the bank lending process via their administrative power over local banking systems. The allocative power of local governments was further expanded as they were granted the authority to set profit-retention rates for local enterprises. As markets were liberalized, local control of product prices and levels of both income and industrial-commercial taxes were strengthened.

The level of local government control of investment decisions and resource flows directly influenced the evolution of local markets. Local governments with smaller industrial bases often had stronger incentives to encourage firms to rely on markets (Walder, 1995). Compared to governments at higher administrative levels, local governments often had clearer financial incentives and constraints. Governments with larger industrial bases had to ensure that firms provided reliable sources of products, particularly industrial inputs, for other firms in the jurisdiction. The governments thus tended to care more about maintaining a stable supply of inputs rather than minimizing the marginal cost of production (Walder, 1992, 1995). However, local governments at lower administrative levels had fewer nonfinancial interests 
in firms, and their revenues were more closely linked to firm financial performance. Because they had fewer entities to monitor and because there were fewer bureaucratic barriers to information flow, local governments were more aware of firms' decision making as well, and they were more active in encouraging firms under their supervision to make promarket decisions. This allowed them to make faster and more effective decisions concerning their operation.

In sum, local governments played a critical role in permitting or even encouraging firms to begin to rely on markets for buying productive inputs and selling industrial output. We expect that the more funds the local government allocated to firms under its jurisdiction, the more interest it had in their financial performance and the more likely it was to enforce real budget constraints. Local governments may have played a role in encouraging the development of local markets as well, and they could encourage firms they controlled to operate on the markets. At the same time, however, the local government agencies could shield firms under their control from market pressures. This would reduce competition and encourage firms to experiment with various markets. For these reasons, firms that received local government funds were probably more likely to use markets for obtaining and selling products than firms that did not receive funds from the local government. Moreover, firms with local government capital likely used product markets for a larger portion of their total transactions than other firms.

While it was still rare, some firms did begin to use other external finance sources during the 1980s. Issuing bonds, in particular, gradually became more popular beginning in the 1980s. By the end of 1986, a total of 10 billion yuan worth of firm bonds had been issued (Gao and Zhuang, 1999). Relative to obtaining bank loans, issuing bonds was risky because it required a serious repayment commitment from the firm, whereas the central state could forgive grants or loans if it deemed forgiveness necessary. Yet central state authorities regulated bond issues more closely than they did other nonstate sources of funds, and the state did occasionally rescue firms that encountered capital emergencies as a result of bad bond issues. Thus issuing bonds was more similar to receiving funds from the central government than to obtaining nonstate capital, and firms that issued bonds may not have faced the same uncertainties that other firms faced. As a result, the internal incentives and external pressures these firms faced would have discouraged experimentation with markets. Therefore, firms that issued bonds were probably less likely to use markets for obtaining and selling products than firms that did not issue bonds. Firms that issued bonds were also likely to use product markets for a smaller portion of their total transactions than other firms. 


\section{RESEARCH DESIGN}

\section{Data}

To test these ideas empirically, we used 1980-1989 panel data on 769 enterprises in four provinces (Sichuan, Jiangsu, Jilin, and Shanxi). The data set is particularly unique among data on Chinese firms during transition because it contains information on firm-level decision making. Such detail is critical to understanding the process by which firms adapted to reform and thus to markets, although firm-level data from China's transition is extremely rare. These data were collected by the Institute of Economics of the Chinese Academy of Social Science (CASS) together with economists from the University of Michigan, Oxford University, and the University of California, San Diego. The Chinese Provincial System Reform Commissions (the agencies responsible for implementing and evaluating reform measures) sent questionnaires to 800 enterprises, and 769 were returned. The response rate was high because the System Reform Commission is a government agency with which the enterprises have regular contact, although it does not directly oversee enterprise activity. The questionnaire had two parts. The first was a set of 70 questions regarding the enterprise structure, manager appointment, contracts, bonus and motivation systems, relations with governmental offices, and enterprise strategy. The second part included 321 quantitative questions, designed to be answered by the enterprise's accountant, covering many aspects of enterprise operations between 1980 and 1989 (Groves et al., 1994, 1995).

All firms included in the CASS sample were state-owned enterprises, and the sample appears to reasonably represent the state-run industry on all dimensions except for firm size. The sample does appear to overrepresent large SOEs, enterprises for which progress in reform has been modest relative to small enterprises and those in the nonstate sector. On key test variables, the sample is consistent with other estimates of firm traits during the 1980 s. The majority (71\%) of the firms in this sample were subordinate to municipal governments. The remainder of the firms were subordinate to the central government $(8.6 \%)$, provincial governments $(10 \%)$, and county governments $(9 \%)$.

\section{Dependent Variables}

We used two sets of analyses to investigate changes in firm adaptation to markets during China's early transition. The first set explored the likelihood that firms obtained four material inputs or sold products on markets. 
The second set of analyses explored the factors that were associated with the proportion of inputs that firms obtained through markets and the proportion of sales conducted over markets. The dependent variable for the first set of analyses was a single, multicategory variable, indicating whether the firm obtained any of four inputs on markets: raw materials, subsidiary materials, fuel, and power. Because many firms acquired more than one of these inputs on a market, four separate dummy variables did not capture the rich combinations of market exposure found among the firms. For this reason, rather than creating four standard dummy variables, we created a multicategory variable that reflected the complete pattern of a firm's adaptation to markets for inputs. For example, if the firm received only raw materials on a market, we coded the variable 1000. Likewise, if the firm received each of the inputs on markets, we coded the variable 1111 . We coded any nonzero transaction in a market as evidence of participation in markets for the particular input. We also estimated a separate model of output sales, coded as 1 for those firms reporting market sales.

Dependent variables in the second set of analysis included (1) the ratio of total raw material inputs purchased at market prices to total raw material inputs purchased at state-planned prices, and (2) the ratio of total sales at market prices to total sales at state-planned prices. We logged both ratios to reduce skewness.

\section{Independent Variables}

We included several measures of financial conditions and resources in each model. Where appropriate, we lagged the independent variable 1 year to approximate appropriate causal ordering. We measured financial market development in the previous year as the ratio of private banks to stateowned banks in the local area (from state statistical data). We included a (logged) indicator of total funds received in the previous year from the central government. We included separate (logged) indicators of total bank loans received during 1980-1984 (giving firms a year to react to the 1983 legislation) and 1985-1989 to test hypotheses about bank finance. We measured (logged) local government funds in the previous year as total state funds that were not distributed by the central government, including provincial, prefectural, county, and municipal funds. ${ }^{4}$ Bonds are the (logged) total value of public bonds issued by the enterprise in the previous year.

\footnotetext{
${ }^{4}$ Including separate indicators of these variables does not improve model fit, nor does it alter the substance of the results. We use the aggregated measure of local funds in order to preserve degrees of freedom.
} 
We controlled for firm traits that may have affected adaptation to markets. Specifically, we controlled for competition from nonstate firms using the ratio of nonstate firms to state firms in the province that may have deterred SOEs from entering markets (Jefferson and Rawski, 1994; Naughton, 1994). We also controlled for (logged) retained earnings, profits, and total assets because (1) reliance on markets might vary with expected returns from market-oriented behavior, and (2) financial security (profits) and size (assets) might encourage experimentation with market exchange. Because access to markets differs across industries in China, we included four dummy variables indicating whether the firm was in the chemical, building material, machinery, or electronics sectors. We controlled for the number of temporary workers (logged) as an indicator of progressivity. Firms that employed more temporary workers are more progressive because temporary employment is a quintessential market practice. Progressive firms may move to markets sooner than their more cautious counterparts. Finally, we controlled for age, as older firms may be more secure about engaging in innovative behaviors. Age squared controls for the likelihood that the effect of age diminishes at larger values. ${ }^{5}$

To control for the possibility that manager's traits shaped firm behavior, we included measures of the manager's Communist Party affiliation and education using three dummy variables: whether the manager is a Party member, graduated from technical school, or graduated from college. Finally, we represented time with a continuous indicator of year ranging from 1980 to 1989 to capture changes in firm behavior as China's transition progressed. Table I presents means, standard deviations, and correlations among the variables in our analysis.

\section{MODEL SPECIFICATION}

To explore the processes that influenced market adaptation, we modeled how firms obtained material inputs and sold output on markets over the 1980-1989 period. First, we used high-dimensional, multivariate probit (HDMP) analysis to model the likelihood that firms obtained four inputs from markets. The dependent variable was the variable indicating whether the firm used markets for any of the following inputs and output: raw materials, subsidiary materials, fuel, and power. It is possible to estimate the likelihood that firms purchased any of the four types of inputs with separate logistic or probit equations. However, because firms may have simultaneously obtained each of the inputs on markets, using a dependent variable

\footnotetext{
${ }^{5}$ We do not control for level of subordination (ownership) in the government hierarchy because it is highly correlated with sources of funding.
} 


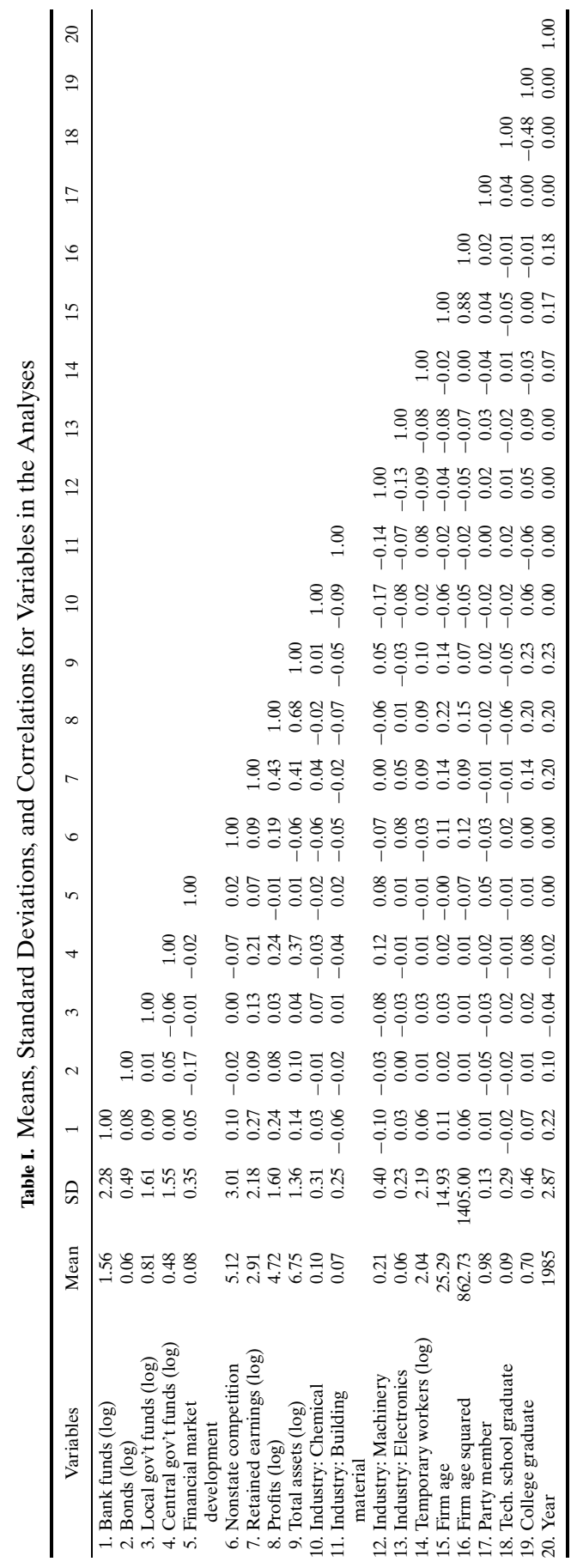


that allows the firms to be in multiple categories at the same time more accurately represents the real situation we are trying to model. HDMP is a form of probit analysis for multiple-response variables that allows respondents to choose multiple outcomes at the same time (Bock and Gibbons, 1996). Moreover, HDMP coefficient estimates are much more accurate than logistic or probit regression when it is possible for respondents to be concurrently in more than a single category (Bock and Gibbons, 1996). For this reason, we opted to use HDMP rather than standard logistic or probit regression. Practically, HDMP coefficient estimates are interpreted identically to logistic or probit coefficients.

Second, to explore the extent of a firm's commitment to markets, we estimated generalized least-squares models of the proportion of input and output transactions conducted on markets. The unit of analysis is the firm-year between 1980 and 1989, and both independent and dependent variables can change each year. We used Estimated Generalized Least Squares (EGLS) regression to estimate the models because the error terms were both heteroskedastic and correlated over time. ${ }^{6}$ EGLS is a technique that allows us to produce more accurate statistical tests by correcting estimates of the errors of the coefficients when the data violate ordinary least-squares assumptions. Practically, EGLS coefficients are interpreted identically to Ordinary Least Squares coefficients.

\section{RESULTS}

\section{Financial Market Development Encouraged Use of Product Markets}

Figure 1 demonstrates that firms increasingly relied on markets during the 1980s. Table II presents HDMP analyses of the processes that affected these changes. In particular, the analyses explore the likelihood that firms purchased raw materials, subsidiary materials, fuel, and power on markets between 1980 and 1989. The table also includes logistic regression analysis results of the likelihood that firms sold output on markets in the same years. The results reveal that firms located in areas where financial markets were more developed were more likely to rely on markets for both material inputs and output sales. This result suggests, consistent with our argument, that firm managers who were more certain about market conditions and had

\footnotetext{
${ }^{6}$ The White's test for heteroskedasticy was significant, and the Ordinary Durbin-Watson Test (D-W) for first-order autocorrelation was significantly different from two. Because the Ordinary D-W was significant, it was not necessary to use the General D-W for high orders of autocorrelation. Practically, we used the Yule-Walker method, also known as the two-step full transform method or Estimated Generalized Least Squares, in SAS Proc Autoreg to estimate the models (Greene, 1993; Judge et al., 1982:442-446; Ostrom, 1978:53-55).
} 




Fig. 1. Percentage of firms obtaining inputs and selling output on market.

more opportunities to engage markets were more likely to experiment with innovative strategies. Table III presents generalized least-squares models of the degree to which firms relied on markets for the acquisition of material inputs and output sales. The findings in Table III are also consistent with our arguments. Both ratios of market-to-plan purchases and sales are positively related to financial market development, all other factors held constant. This suggests that managers located in areas with relatively well-developed financial markets made bigger commitments to using product markets.

There are both direct and indirect reasons for these findings. The direct explanation is that managers in areas with developed financial markets had better access to capital to fund expansion and experimentation. They were also more likely to encounter potential exchange partners who had the same freedom. This suggests that strategically, the managers were more certain than their counterparts in less developed areas of the likely benefits and long-term potential of such exchange. That is, consistent with strategic choice arguments, they probably perceived that, given the conditions they experienced, their firms had the capability to be competitive in market exchange. These findings also suggest that managers were more confident in the stability of markets because they were exposed to developing markets of various sorts. This measure does not indicate that product markets were stable but that a related market was developed. In areas where markets are stable, the contextual conditions encourage experimentation and may even produce normative pressures to use markets. Our findings do not demonstrate these arguments specifically, but they are consistent with both the direct and indirect explanations. 


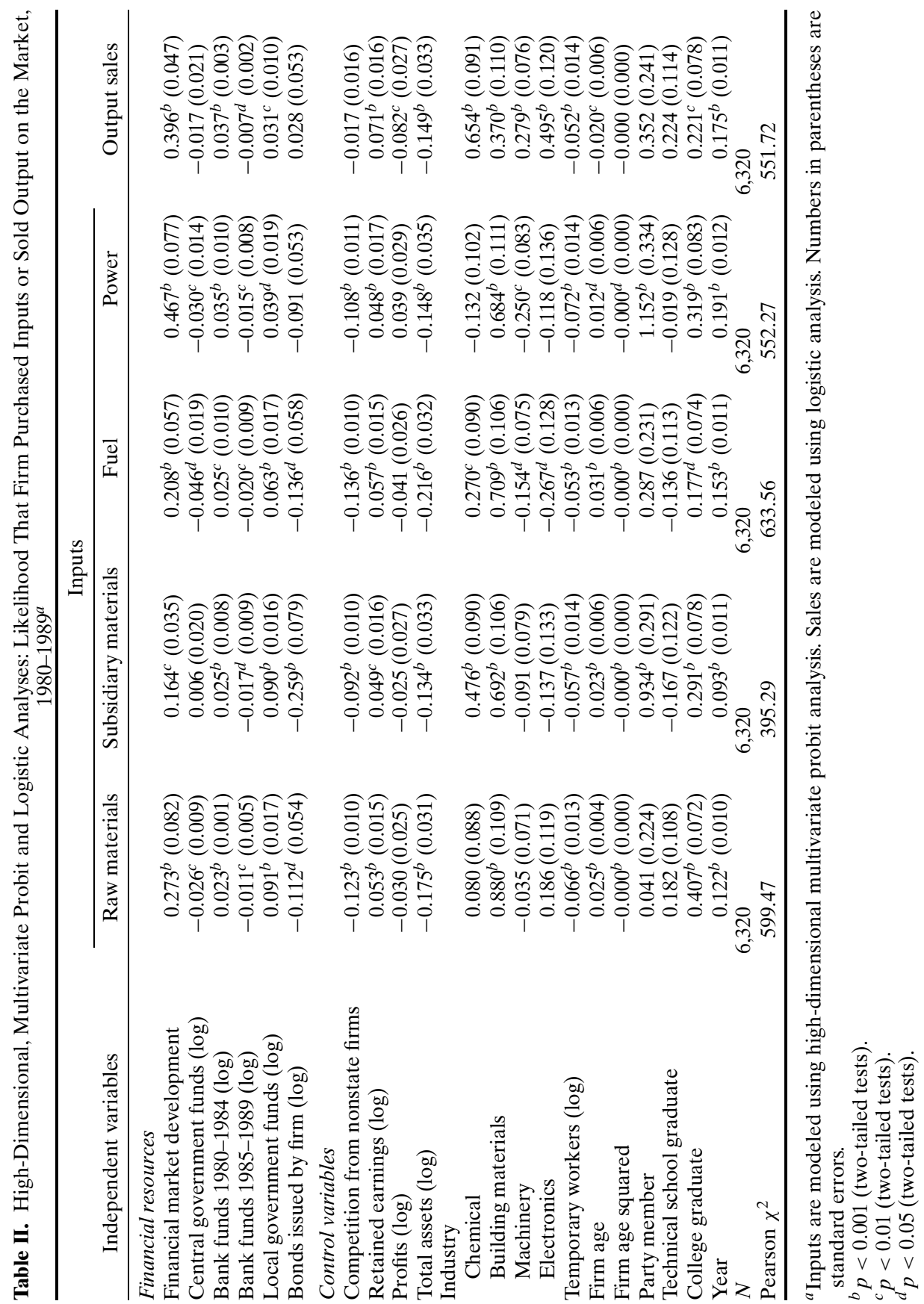


Table III. EGLS Regression Analysis: Commitment to Markets for Inputs and Sales, $1980-1989^{a}$

\begin{tabular}{lcc}
\hline & $\begin{array}{c}\text { Market inputs/ } \\
\text { planned inputs }\end{array}$ & $\begin{array}{c}\text { Market sales/ } \\
\text { planned sales }\end{array}$ \\
\hline Financial resources & & \\
Financial market development & $0.320^{b}(0.060)$ & $0.578^{b}(0.081)$ \\
Central government funds $(\log )$ & $-0.130^{b}(0.03)$ & $-0.140(0.080)$ \\
Bank funds 1980-1984 $(\log )$ & $0.160^{c}(0.06)$ & $0.410^{d}(0.180)$ \\
Bank funds 1984-1989 $(\log )$ & $-0.029^{d}(0.015)$ & $-0.031^{d}(0.012)$ \\
Local government funds $(\log )$ & $0.049^{c}(0.017)$ & $0.046^{d}(0.020)$ \\
Bonds issued by firm $(\log )$ & $-0.067^{d}(0.032)$ & $-0.094^{c}(0.022)$ \\
Control variables & & \\
Competition from nonstate firms & $-0.049^{b}(0.009)$ & $-0.033^{d}(0.014)$ \\
Retained earnings $(\log )$ & $-0.020(0.014)$ & $0.036(0.023)$ \\
Profits $(\log )$ & $0.009(0.025)$ & $-0.097^{c}(0.036)$ \\
Total assets $(\log )$ & $-0.169^{b}(0.030)$ & $-0.140^{c}(0.044)$ \\
Industry & & \\
$\quad$ Chemical & $-0.169(0.078)$ & $0.623^{b}(0.131)$ \\
Building materials & $-0.063(0.105)$ & $0.625^{b}(0.156)$ \\
Machinery & $-0.810^{b}(0.071)$ & $0.449^{b}(0.105)$ \\
$\quad$ Electronics & $0.045(0.119)$ & $0.918(0.176)$ \\
Temporary workers $(\log )$ & $-0.004(0.011)$ & $-0.019(0.018)$ \\
Firm age & $0.010^{d}(0.004)$ & $-0.034^{b}(0.006)$ \\
Firm age squared & $0.000^{c}(0.000)$ & $0.000^{d}(0.000)$ \\
Party member $(1=$ yes) & $0.536^{d}(0.212)$ & $0.631^{d}(0.300)$ \\
Technical school graduate $(1=$ yes $)$ & $-0.036(0.106)$ & $-0.030(0.157)$ \\
College graduate $(1=$ yes $)$ & $0.094(0.071)$ & $0.098(0.104)$ \\
Year & $0.123^{b}(0.010)$ & $0.179^{b}(0.015)$ \\
$N=6,320$ & & \\
$R^{2}$ & 0.066 & 0.062 \\
\hline
\end{tabular}

${ }^{a}$ Numbers in parentheses are standard errors.

${ }^{b} p<0.001$ (two-tailed tests).

${ }^{c} p<0.01$ (two-tailed tests).

${ }^{d} p<0.05$ (two-tailed tests).

\section{Capital Sources Shaped Movement To Product Markets}

The results also provide support for the idea that capital sources affect the use of product markets differentially. Receiving central government funds, for example, reduces the use of product markets. In Table II, receiving central government funds has a negative effect on market purchases of raw materials, fuel, and power. It also reduces sales on markets. Similarly, the results reported in Table III indicate that receiving central government funds reduces firms' level of reliance on markets for both input purchases and output sales. This is consistent with the argument that while the market context was clearly important, the strong state in China continued to shape a great deal of economic behavior during transition. Again, this does not imply that firms were not strategic actors, nor does it suggest that they 
were immune to institutional pressure. In contrast, the results support the argument that firms that continued to have a strong relationship with the state were less concerned about market uncertainty than their counterparts with weaker ties to the central government.

The changing effect of bank loans following the implementation of grants-for-loans legislation in 1983 illustrates more dramatically the state's role in shaping the behavior of firms. The results provide evidence for our hypotheses that between 1980 and 1984, receiving more bank loans increased reliance on product markets (Table II) and also increased the proportion of resources committed to markets (Table III). However, between 1985 and 1989, this relationship appears to have reversed. This suggests that government action produced a very important change in firm behavior, regardless of whether it was intended to produce this change. In the early 1980s, as markets developed and budget constraints hardened, managers may have applied for bank loans because they were independent. Thus their receipt of these loans may indicate that these firms were not controlled by the state and were free to experiment. Following the 1983 financial reforms, however, our findings suggest that firms that were still receiving loans were a different type of enterprise. In particular, those still receiving bank loans at that point probably had no alternatives because they were not adapting well. Likewise, normative pressure after the 1983 legislation was to use nonbank forms of capital, and those still using bank loans were less likely to behave consistently with other pressures to marketize. In short, these results suggest that state action changed the meaning of both internal strengths and external pressures.

We also proposed that receiving local government funds would increase experimentation with markets, and our results support this proposition. The results in Table II indicate that the more funds a firm received from local governments, the more likely it was to obtain each input and sell output on markets. The results reported in Table III suggest that local government funds also increased a firm's commitment to using markets. These findings are consistent with our proposition that the more funds local governments had invested in industry, the more interest they had in the financial performance of firms under their control and the more they encouraged movement to markets. Again, this finding is consistent with strategic choice arguments that managers assess their capabilities and strengths and draw on those. Yet this is also consistent with institutional arguments suggesting that external pressures determine much about where and how firms innovate. In this case, the relevant contextual influence appears to be the local government. But what is perhaps most interesting is the role that the central state played in determining which influences were most salient for these firms. Because the central government transferred control of many firms to lower-level 
governments, the incentives and pressures these firms felt encouraged them to behave in direct opposition to the firms over which the state maintained control. In particular, those firms that were released by the central state entered markets more rapidly and with greater force than those that stayed under the control of the central state. The long-term implications of this are uncertain, of course, but the immediate implication is that firms not protected by the central government are likely to become more adept at dealing with market exchange and the activities that implies (i.e., raising capital, innovation, competition). This finding also highlights the fact that only firms under the central government were slow to adapt to markets, while those under municipal governments were being reformed.

In addition, we anticipated that firms that issued bonds would be less likely to experiment with product markets. Because issuing bonds was a privilege granted by the government to firms that had closer ties with the state during the early stages of the reform, we projected that these firms would tend to have little incentive to experiment with the emerging markets, as they would often have more secured access to critical resources than those with less connection with the state. The findings in Table II support this argument. The weaker effects of bond issues on power and output sales reported in Table II are probably the result of comparatively less control from the state on final product markets during the early stages of the reform. The state maintained strict controls particularly on raw materials and fuel due to the severe shortage of these resources during the 1980s. The dual pricing system implemented in 1984 was developed mainly to regulate transactions involving these commodities (Naughton, 1995:220-227). The effects of factors such as connections with the state become more evident with regard to whether firm managers actively sought access to markets for these purchases. ${ }^{7}$

Our findings also demonstrate that competition from nonstate firms is negatively related to a firm's reliance on markets for both input purchases and output sales. The degree to which local markets were developed shaped firm adaptation in ways that may seem counterintuitive but that are perfectly consistent with managerial efforts to reduce risk. In transition economies where uncertainty associated with poorly developed markets was particularly salient, managers were particularly attuned to the need to protect their interests (Guthrie, 1997; Keister, 2001; Peng, 2000). Yet local and, to some degree, national incentives encouraged experimentation with market practices. In areas where markets were poorly developed, firms probably

\footnotetext{
${ }^{7}$ This paper explores the effect of market development and funding sources, not entry into financial markets, on experimentation with product markets. Similar processes affect entry into financial markets and labor markets (Keister, 2002), and it is possible that firms enter multiple markets simultaneously. Our lagged independent variables approximate appropriate causal order. Future research might explore in more detail the dynamics of market-entry timing.
} 
perceived that there was less competition or less risk associated with competition. Thus they were likely to perceive less risk associated with market transactions. As a result, firms located in areas with relatively poorly developed product markets were more likely to experiment with this new form of exchange than their counterparts in areas with more developed markets.

In contrast, retained earnings were positively related to market experimentation. This finding is consistent with research showing that retained earnings affected firm-level decision making and market adaptation during transition (Keister, forthcoming). Firms with greater retained earnings probably felt more confident about taking risks such as experimenting with markets.

Several other control variables also shaped reliance on markets for obtaining inputs and selling output. Results reported in Tables II and III also demonstrate that total assets had a strong negative effect on firm adaptation to markets; however, profits were uncorrelated with the likelihood that firms purchased inputs on markets. Firms in the building materials sector were more likely than others to rely on markets, whereas those in other sectors did not demonstrate notable patterns. The number of temporary workers had a significant and negative effect on market transactions; firm age was positively associated with market purchases but negatively associated with market sales. Finally, managers who were college graduates or Party members were more likely to use markets for both inputs and sales. The results presented in Table III demonstrate similar patterns.

\section{DISCUSSION AND CONCLUSION}

This study explored the process by which firms made the transformation from relying on a state planning system to using markets for buying and selling industrial products during China's economic transition. We used highdimensional multivariate probit analysis to analyze the likelihood that firms purchased inputs or sold outputs on the market from 1980 to 1989 . The results suggested that firms located in areas where financial markets were welldeveloped were more likely to use product markets and committed a larger portion of their resources to using markets. We also found that the sources of funds through which a firm raised capital shaped movement to markets. The more funds a firm received from the central state, for example, the less likely it was to experiment with product markets and the less it committed to product markets if it made the transition. This finding was consistent with our argument that firms receiving central state funds were probably high priorities and thus faced a different set of institutional constraints than their counterparts that were more independent. For some of the same reasons, 
we found that firms that issued bonds-those with stronger central state ties-also relied less on product markets.

We also documented an important effect that the central state had on firm movement to markets by showing that the effect of receiving bank loans reversed after the state implemented grants-for-loans legislation in 1983. Prior to 1983 , receiving bank loans indicated that a firm was a low state priority and that it had the autonomy to raise nonstate capital, including capital from banks. As a result, in the early reform years, firms with bank loans were more likely to experiment with product markets and committed a larger portion of their resources to market transactions. After 1984, however, firms that received loans were less likely to rely on markets to buy and sell industrial products, and they committed less of their overall transactions to the market. This suggests that the state's effort to privatize banks also affected what types of firms received bank loans and how those firms approached other markets. Similarly, our results also indicated that the use of markets was influenced in important ways by connections to local governments. Firms under the control of lower-level governments were less constrained and had greater flexibility to make decisions regarding experimentation with markets. Because our data allow us to explore adaptation at the firm level, our findings speak to the process by which real organizations made this important transition during a critical period in China's history. Moreover, because we draw on ideas from organization theory, our findings begin to address another important void in the literature on Chinese firms: the absence of applications of accepted Western ideas to new contexts.

Our findings have important implications for understanding firm behavior more generally. Research on innovative firm behavior in the West has largely been restricted to explanations that emphasize internal, strategic factors or external, institutional factors. Our results suggest that, in reality, firms make strategic decisions that take firm capabilities into account and also react to external institutional constraints. Few organization theorists would dispute our central contention that both internal and external processes are important, but the relative weight of these influences has not been clear in the past. Our findings suggest that an important factor determining the relative salience of internal and external influences is the state. The state seldom enters strategic choice analyses, and it enters most institutional analyses as an afterthought. Yet our results suggest that the state can and, in some contexts, does determine which factors will be relevant and when they will matter. In the specific case of China's transition, the state determined which firms it would continue to control and which it would release to local government control or to the market. This act determined the relative mix of internal and external constraints that firms faced in the short run. In the long run, the central state's decisions about which firms to protect initially is 
likely to influence which firms are adept at negotiating market exchange and which remain weak dinosaurs. Of course, there are some industries that are protected in nearly all economies (e.g., defense), and the mere presence of state control does not necessarily imply reduced competition. This does suggest, however, that future research might explore cross-national differences in state intervention in the economy and how this affects the incentives to which managers respond.

Naturally, these results have important implications for understanding China, the nature of transition in China, and the role that the institutional context of reform has for the behavior of firms. The desire for autonomy, the importance of government involvement, and regional variations in market development and competition all shaped a firm's transition to reliance on markets for transactions in important ways. Some fundamental principles of firm behavior that are accepted in Western research on organizational theory were evident in the behavior of Chinese firms; however, the implications of these principles for strategic decision making about input and output were very different in the transition context. The findings of this study thus speak more generally to literature on institutional context. Natural extensions of this study would explore the role of institutional context in more depth in the formation of other corporate strategies during transition.

\section{ACKNOWLEDGMENTS}

We are grateful for research support from the National Science Foundation (SES 987514) and for comments from Randy Hodson and Jim Moody.

\section{REFERENCES}

\section{Barnett, William P.}

1993 "Strategic deterrence among multipoint competitors." Industrial and Corporate Change 2:249-278.

Barney, Jay

1986 "Strategic factor markets: Expectations, luck, and business strategy." Management Science 32:12311241.

1991 "Firm resources and sustained competitive advantage." Journal of Management 17:99-120.

Bock, Darrell, and Robert D. Gibbons

1996 "High-dimensional multivariate probit analysis." Biometrics 52:1183-1194.

\section{Buchko, Aaron A.}

1994 "Barriers to strategic transformation." Advances in Strategic Management 10:81-106.

\section{Byrd, William A.}

1989 "Plan and market in the Chinese economy: A Simple General Equilibrium Model." Journal of Comparative Economics 13:177-204.

Dess, Gregory G., and Donald W. Beard

1984 "Dimensions of organizational task environments." Administrative Science Quarterly 29:52-73.

DiMaggio, Paul J., and Walter W. Powell

1983 "The iron cage revisited: Institutional 
isomorphism and collective rationality in organizational fields." American Sociological Review 48:147-160.

\section{Dougherty, Deborah}

1994 "Commentary." Advances in Strategic Management 10:107-112.

Dutton, Jane E., and Robert B. Duncan

1987 "The creation of momentum for change through the process of strategic issue diagnosis." Strategic Management Journal 8:94-121.

Gao, Peiyong, and Yuming Zhuang

1999 Zhongguo Zhaiquan Shichang Toushi [China's bond market]. Beijing: Zhongguo Caizheng Jinrong Chubanshe.

\section{Ginsberg, Ari}

1988 "Measuring and modeling changes in Strategy: Theoretical foundations and empirical directions." Strategic Management Journal 9:365-377.

\section{Goldie-Scott, Duncan}

1995 Banking in China. London: Financial Times Publishing.

\section{Greene, William}

1993 Econometric Analysis, 2nd edn. New York: Macmillan.

Greenwood, Royston, and C. R. Hinings

1996 "Understanding radical organizational change: Bringing together the Old and the New Institutionalism." Academy of Management Review 21:10221054.

Groves, Theodore, Yongmiao Hong, John

McMillan, and Barry Naughton

1994 "Autonomy and incentives in Chinese state enterprises." Quarterly Journal of Economics 109:183-209.

1995 "China's evolving managerial labor market." Journal of Political Economy 103:873-891.

Guthrie, Douglas

1997 "Between markets and politics: Organizational responses to reform in China." American Journal of Sociology 102:1258-1304.

Haunschild, Pamela R., and Anne S. Miner

1997 "Modes of interorganizational imitation: The effects of outcome salience and uncertainty." Administrative Science Quarterly 42:472-500.

Holz, Carston

1992 The role of central banking in China's economic reforms. Ithaca, NY: Cornell University East Asia Program.
Jefferson, Gary H., and Thomas G. Rawski

1994 "Enterprise reform in Chinese industry." Journal of Economic Perspectives 8:47-70.

Judge, George G., R. Carter Hill, William E. Griffith, Helmat Lütkepoh, and Tsoung-Chao Le

1982 Introduction to the theory and practice of econometrics. New York: Wiley.

Keats, Barbara W., and Michael A. Hitt

1988 "A causal model of linkages among environmental dimensions, macro organizational characteristics, and performance." Academy of Management Journal 31:570-598.

Keister, Lisa A.

2000 Chinese Business Groups: The Structure and Impact of Interfirm Relations During Economic Development. New York: Oxford University Press.

2001"Exchange structures in transition: Lending and trade relations in Chinese business groups." American Sociological Review 66:336-360.

2002 "Adapting to radical change: A longitudinal study of the adoption of piece rates in China." Organization Science 13:459-474.

2004 "Capital structure in transition: Financial strategy in China's emerging economy." Organization Science 15:145158.

Kelly, Dawn, and Terry L. Amburgey

1991 "Organizational inertia and momentum: A dynamic model of strategic change." Academy of Management Journal 34:591-612.

\section{Kornai, Janos}

1979 "Resource-constrained versus demand-constrained systems." Econometrica 47:801-820.

1986 Contradictions and Dilemmas: Studies on the Socialist Economy and Society. Cambridge, MA: MIT Press.

1992 The Socialist System: The Political Economy of Communism. Princeton, NJ: Princeton University Press.

Lardy, Nicholas R.

1998 China's Unfinished Economic Revolution. Washington, DC: The Brookings Institution Press.

Leblebici, Huseyin, Gerald R. Salancik, Anne Copay, and Tom King

1991 "Institutional change and the transformation of interorganizational fields: 
An organizational history of the U.S. radio industry." Administrative Science Quarterly 36:333-363.

Meyer, John W., and Brian Rowan

1977 "Institutionalized organizations: Formal structure as myth and ceremony." American Journal of Sociology 83:340-363.

Naughton, Barry

1994 "China's reforms: Structural and welfare aspects; Chinese innovation and privatization from below." American Economic Review 84:266270.

1995 Growing Out of the Plan: Chinese Economic Reform, 1978-1993. Cambridge, New York, and Melbourne: Cambridge University Press.

Nelson, Richard R., and Sidney G. Winter

1982 An Evolutionary Theory of Economic Change. Cambridge, MA: Harvard University Press.

\section{Oliver, Christine}

1991 "Strategic responses to institutional processes." Academy of Management Review 16:145-179.

O'Neill, Hugh M., Richard W. Pouder, and Ann K. Buchholtz

1998 "Patterns in the diffusion of strategies across organizations: Insights from the innovation of diffusion literature." Academy of Management Review 23:98-114.

Ostrom, Charles W., Jr.

1978 Time Series Analysis: Regression Techniques. Beverly Hills, CA: Sage.

Peng, Michael W.

2000 Business Strategies in Transition Economies. Thousand Oaks, CA: Sage.

\section{Penrose, Edith}

1959 A Theory of the Growth of the Firm. New York: Wiley.

Pfeffer, Jeffrey, and Gerald R. Salancik

1978 The External Control of Organizations: A Resource Dependence Per- spective. New York: Harper and Row.

Strang, David, and John W. Meyer

1993 "Institutional conditions for diffusion." Theory and Society 22:487-512.

Tichy, Noel M.

1983 Managing Strategic Change. New York: Wiley.

Tolbert, Pamela S., and Lynne G. Zucker

1983 "Institutional sources of change in the formal structure of organizations: The diffusion of Civil Service Reform, 1880-1935." Administrative Science Quarterly 28:22-39.

\section{Walder, Andrew G.}

1992 "Property rights and stratification in socialist redistributive economies." American Sociological Review 57:524-539.

1995 "Local governments as industrial firms: An organizational analysis of China's transitional economy." American Journal of Sociology 101:263301.

\section{Wong, Christine}

1986 "The economics of shortage and problems of reform in Chinese industry." Journal of Comparative Economics 10:363-387.

Wu, Jinglian, and Renwei Zhao

1987 "The dual pricing system in China's industry." Journal of Comparative Economics 11:309-318.

Xu, Xiaoping

1998 China's Financial System under Transition. New York: St. Martin's Press.

\section{Yi, Gang}

1994 Money, Banking, and Financial Market Emergence in China. New York: Westview.

Zucker, Lynne G.

1977 "The role of institutionalization in cultural persistence." American Sociological Review 42:726-743. 